J Arid Land (2015) 7(6): 741-754

doi: 10.1007/s40333-015-0011-6

jal.xjegi.com; www.springer.com/40333

\title{
Drought analysis in Antakya-Kahramanmaraș Graben, Turkey
}

\author{
Murat KARABULUT* \\ Department of Geography, Kahramanmaraş Sütçü İmam University, Kahramanmaraş 46100, Turkey
}

\begin{abstract}
The most parts of the Earth experience precipitation variability as a part of their normal climates over both short- and long-time periods. These variations of precipitation will have unpredictable and perhaps unexpectedly extreme consequences (such as drought and flood) with respect to frequency and intensity for many regions of the Earth. Because of high precipitation fluctuations, the Mediterranean region is also the areas of the world sensitive to precipitation changes which often involve frequent drought conditions in Turkey. In this study, drought conditions at annual, seasonal and monthly time scales over the period of 1975-2010 were examined for Antakya-Kahramanmaraş Graben which is located in the eastern part of the Mediterranean region of Turkey. Application of appropriate measures to analyze and monitor droughts is recognized as a major challenge to scientists involved in atmospheric studies. Standardized Precipitation Index (SPI) and cumulative deviation curve techniques were used to determine drought conditions. Results indicated that the study area presented a cyclic pattern of variations with alternating drier and wetter years. From analyses of annual, seasonal and monthly drought series it can be seen that precipitation characteristic of the area is changing. By the results, apparent wet and dry periods can be distinguished. This study also indicated that precipitation totals of winter, spring and summer seasons were slightly decreased during the study period. Drought frequency was increased especially for the northern part of the area in the last ten years. Drought periods were divided into 1982-1985, 1999-2002 and 2004-2008, respectively. According to our analyses, the time scale of 1999-2002 was the driest period in the most of the graben area. The study area, which covers agriculturally important fertile alluvial plains, will experience increasing pressure on its water resources because of its growing population and industry, ever-larger demands for intensive agricultural activities, and frequent drought events.
\end{abstract}

Keywords: climate variability; drought; standardized precipitation index; Antakya; Kahramanmaraş; Turkey

Citation: Murat KARABULUT. 2015. Drought analysis in Antakya-Kahramanmaraş Graben, Turkey. Journal of Arid Land, 7(6): 741-754. doi: $10.1007 /$ s40333-015-0011-6

Precipitation is a dynamic climate phenomenon that varies across temporal and spatial scales throughout the world. Understanding its behavior is important in solving problems in terms of global climate change, agricultural production, food security and health of ecosystem. The examination of fluctuations to precipitation time series produces useful information for the understanding of past, current and future climates. Thus, in recent studies, the focus on precipitation change and variability relies mostly on the determination of trends in instrumental records of this climatic parameter which depicts water scarcity of specified region. Numerous researches of precipitation trends have recently been conducted at different periods of records throughout the world and Turkey (Türkeş, 1996a; Kadıoglu, 2000; Lazaro et al., 2001; Ramos, 2001; Yue and Türkeş, 2002; Hashino, 2003; Türkeş, 2003). With climate change scenarios of precipitation, drought risk will generally increase across most of the world (Türkeş, 2001; Beniston, 2007). Drought is one of the most common natural disasters and the most costly in terms of economic damage throughout the history of the world. During the last three decades, a series of drought had occurred in the world and caused

*Corresponding author: Murat KARABULUT (E-mail: mkarabulut@ksu.edu.tr)

Received 2015-01-09; revised 2015-03-31; accepted 2015-04-12

(C) Xinjiang Institute of Ecology and Geography, Chinese Academy of Sciences, Science Press and Springer-Verlag Berlin Heidelberg 2015 
severe property and damages such as the year of 1989 . Concerns about the risk of drought have increased due to upward trend of temperature. Because of significant impact of drought on human activities, this phenomenon is a highly popular topic within the scientific communities (Türkeş, 1996b; Bordi et al., 2001; Khalil and El-Kadi, 2001; Türkeş, 2001; Burn and Elnur, 2002; Bonaccorso et al., 2003; Sirdaş and Şen, 2003; Karabörk, 2007; Türkeş and Tatli, 2009; Türkeş, 2011; Tabari et al., 2012; Shahabfar and Eitzinger, 2013).

As a recurring climatic phenomenon, drought frequently occurred not only in many parts of Turkey but also in many regions around the world (Koçman et al., 1995; Türkeş, 2001; Pamuk et al., 2004; Türkeş et al., 2009a; Kömüşçü and Erkan, 2011) and several regions of the world (Khalil and El-Kadi, 2001; Khan et al., 2008). Drought brought significant water shortages, economic losses and worse social consequences (Sönmez et al., 2005; Karabörk, 2007). Drought preparedness should be established as an important part of national environmental policies to avoid unexpected consequences (Khan et al., 2008). The negative impact of drought varies from one place to another depending upon normal climatic conditions, available water resources, agricultural practices and various socio-economic status of the region. Scientists used techniques to describe and analyze drought and demonstrated its complex nature (Dracup et al., 1980; Wilhite and Glantz, 1995; Khan et al., 2008). According to previous studies, there are four drought types, namely, meteorological, hydrological, agricultural and socio-economic droughts. Meteorological drought can be defined as a condition when there is a significant precipitation decrease compared with the average precipitation over an area (i.e. more than 25\%). Hydrological drought occurs as a result of long-term meteorological droughts which cause diminishing water level of reservoirs, lakes, streams, rivers and groundwater. Agricultural drought happens when soil moisture is deficient to support healthy crop growth during the growing season. Furthermore, socio-economic drought means the properties of the socio-economic consequences caused by the meteorological, hydrological and agricultural droughts (Wilhite and Glantz, 1995). The significance of drought type to a region mainly depends on its geographic characteristics. In the study area, the agricultural and hydrological droughts play important roles.

Drought indices such as Palmer Drought Severity Index (PDSI), Percent of Normal (PN), Reclamation Drought Index (RDI), Surface Water Supply Index (SWSI), Crop Moisture Index (CMI), Drought Severity Index (DSI) and Standardized Precipitation Index (SPI) have been developed to monitor and analyze precipitation fluctuations over years (Smakhtin and Hughes, 2004). The aim of using drought indices is to convert thousands of precipitation data into a comprehensible form. Calculated index values are normally a group of numbers which are more beneficial than raw data for decision making. Even though, any of the developed indices is not naturally excellent, in which SPI is a relatively new index used by many scientists in recent meteorological drought studies. The index developed by McKee et al. (1993) needs less data and computing procedure as compared to other indices. It can be used on different time scales such as 3, 6, 12 and 48 months. This temporal versatility is also useful during the examination of the effects of a precipitation fluctuation on different water resources components (groundwater level, soil moisture characteristics, dams or reservoir storage). The index was used in Europe (Bordi et al., 2005), Turkey (Türkeş, 1996a; Pamuk et al., 2004; Sönmez et al., 2005), Italy (Bordi et al., 2001), Mexico (Giddins et al., 2005), Australia (Khan et al., 2008), Iran (Shahabfar and Eitzinger, 2013), China (Wu et al., 2001), Portugal (Moreira et al., 2006), Sicily (Bonaccorso et al., 2003), Greece (Nalbantis and Tsakiris, 2009) beside other indices for real time observing or analysis of past droughts.

During the last twenty years, the spatial and temporal variations of precipitation and drought conditions were researched in Turkey (Türkeş, 1996a, 1998; Kadıoglu, 2000; Türkeş et al., 2009b). Results of these studies showed that the annual and winter precipitation amount presented a decreasing trend for many regions of Turkey since 1970s. Türkeş et al. (2009b) found that Mediterranean region faced a significant decreasing precipitation trend in winter. Thus, the study area, which is located in eastern part of the Mediterranean region in Turkey (Fig. 1), is most likely 

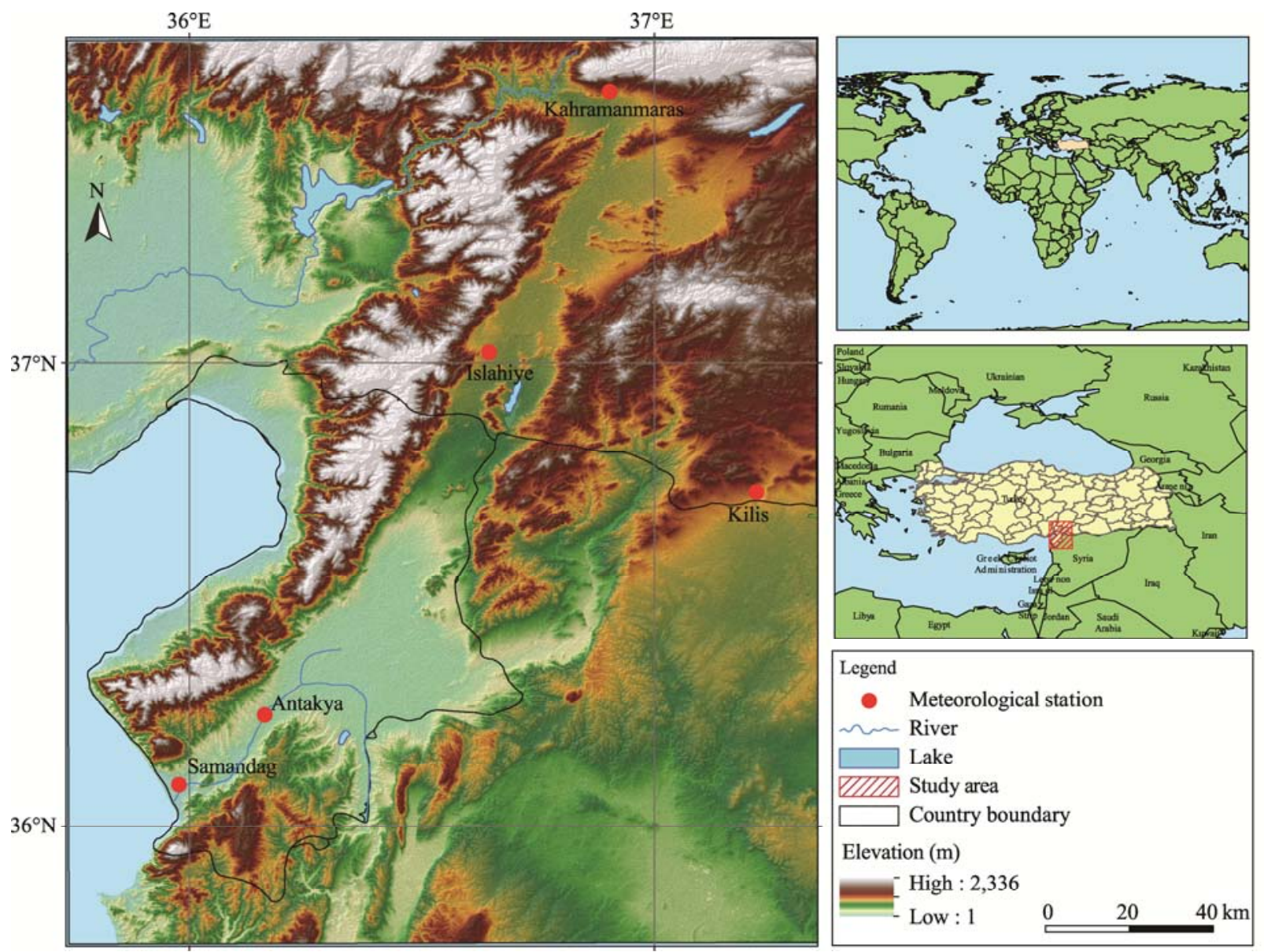

Fig. 1 Location map of the study area and the meteorological stations

to experience strong drought conditions for short- and long-time periods. Climate of the area is characterized by dry, warm-to-hot summers and mild and wet winter. Cycling periods of dry and wet weather are a common climate condition of the area. The area is sometimes subject to extreme climatic variations in their seasonal and inter-annual precipitation, resulting in recurrent droughts and floods. Due to drought events, natural resources, such as vegetation and the existing resources, are easily damaged. Extreme and unexpected climate changes increase stress on renewable water supplies (Eshel and Farrell, 2000; Lazaro et al., 2001; Panu and Sharma, 2002; Beniston, 2007). At the same time, increasing population has added to the growing demand for water and other natural resources in the study area (Huseyinova et al., 2009). The needs for proper quantification of drought impacts, and monitoring and reporting of drought events are of critical importance in politically, economically and environmentally sensitive areas in Turkey. Therefore, it is important to evaluate drought conditions in Antakya-Kahramanmaraş Graben. To achieve our aims, we used precipitation data from 1975 to 2010 in order to identify drought characteristics at different time scales. The main purpose of this research is to explore if variations of precipitation result in the drought conditions that prevail in the study area.

\section{Materials and methods}

The study area has a typical Mediterranean climate with a relatively cool or mild winter and hot summer. According to the Thornthwaite classification method (Thornthwaite, 1948), climate of the area ranges from humid (Antakya) to semi humid (Kahramanmaraş). The precipitation is not evenly distributed throughout the year, predominantly falling in winter and summer if it happens. The average annual precipitation is influenced by the planetary wind pattern, natural geogra- 

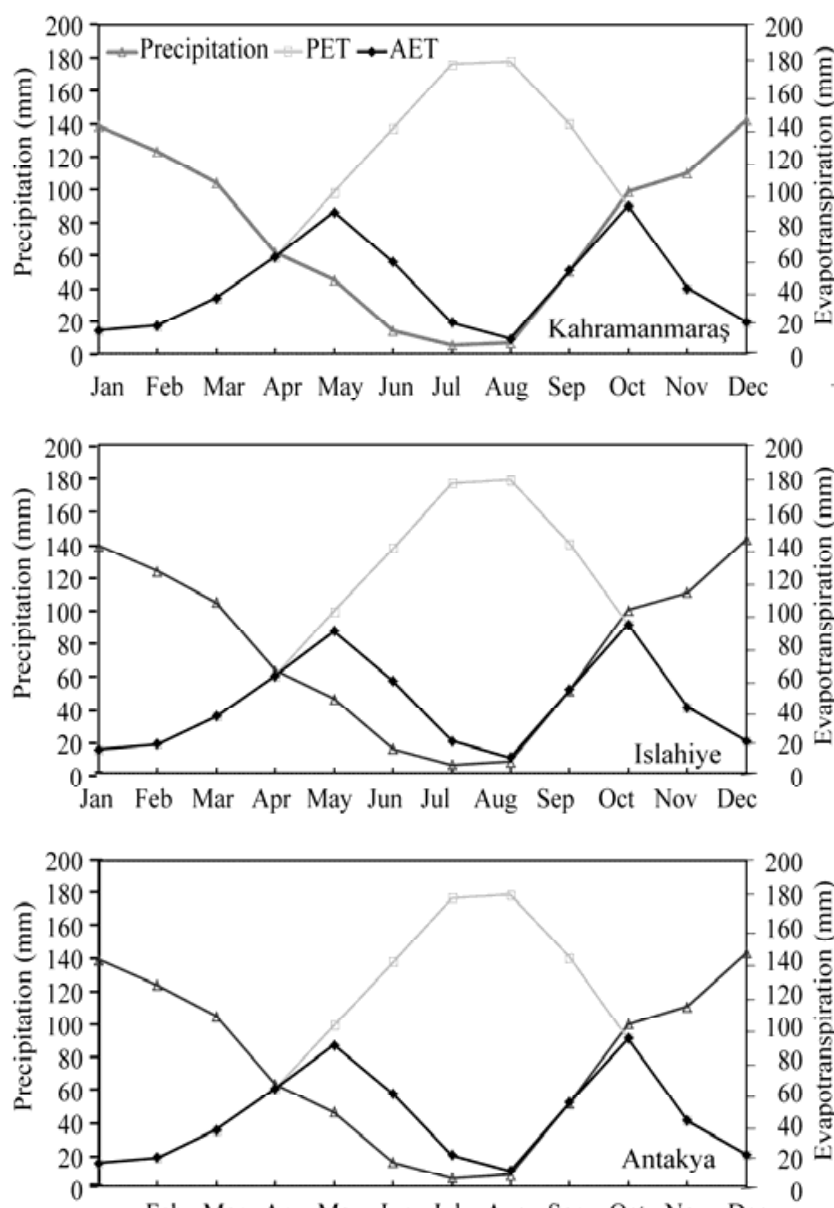

Feb Mar Apr May Jun Jul Aug Sep Oct Nov Dec

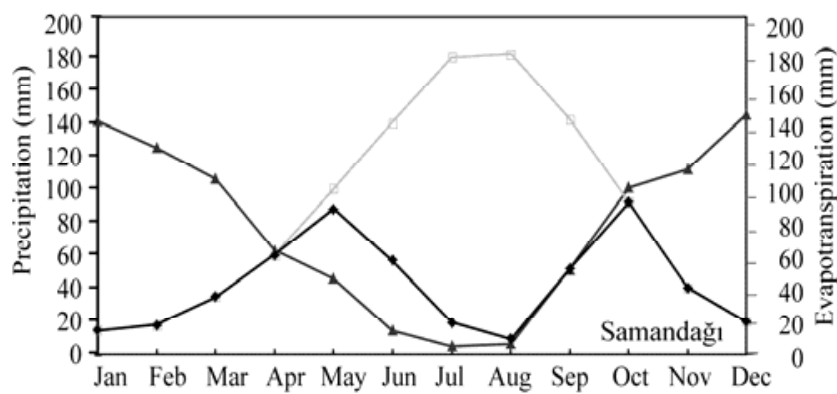

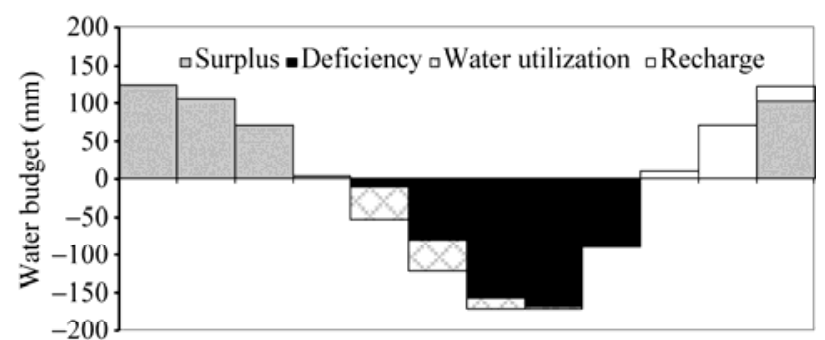

Jan Feb Mar Apr May Jun Jul Aug Sep Oct Nov Dec
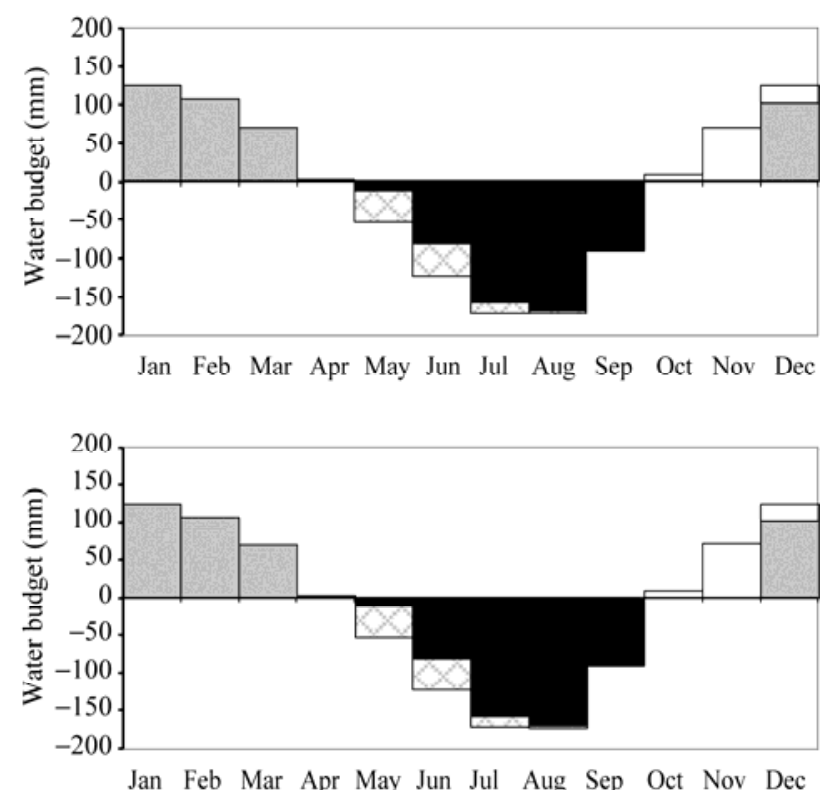

Jan Feb Mar Apr May Jun Jul Aug Sep Oct Nov Dec

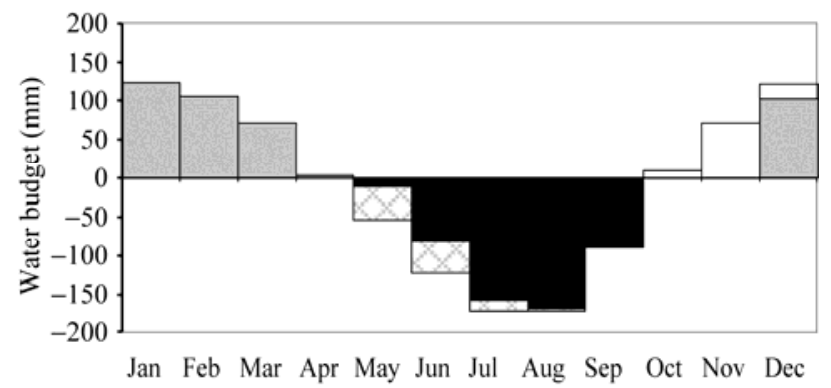

Fig. 2 Precipitation, potential evapotraspiration (PET), actual evapotranspiration (AET) and water budgets of four meteorological stations

phy and topography. The study area belongs to distinctive climatic regime of summer drought and cool moist winters (Fig. 2).

In this study, annual, seasonal and monthly precipitations measured at Kahramanmaraş, Antakya, İslahiye and Samandağ meteorological observation stations were used for the period of 1975-2010 (Turkish Meteorological Service, data were primarily processed). In addition, there are other meteorological stations in the graben, however, the time scale of the meteorological data was less than twenty years and time span cannot be done by any meaningful analysis, thus, only data from four meteorological stations were used. All stations used in this study are located in the eastern part of Mediterranean region where dominated by semi-arid climate. Kahramanmaraş, İslahiye and Antakya occupy east side of the Amanos Mountain and only Samandağ is located next to coastline. According to Türkeş (1998), Kahramanmaraş station belongs to Continental Mediterranean Rainfall Regime 
region (CMED) and rest of them are in Mediterranean Regime region (MED).

The average precipitation amount for the period of 1975-2010 was computed to examine the drought condition which is commonly or generally defined as negative distance from the average. Since this study analyzes the meteorological drought, meteorological season definitions were used for different seasons, that is, summer (June, July and August), autumn (September, October and November), winter (December, January and February) and spring (March, April and May). Due to the importance of water availability for agricultural activities seasonal drought pattern is vital for the study area.

The locations of the stations have not been changed during the study period, verifying the suitability of the data set. The none-parametric Thom's homogeneity was applied to calculate annual precipitation using the following equations (Lazaro et al., 2001). In these formulas, $N$ is equal or larger than 25 , if the series is homogeneous, the distribution of the number of runs $(R)$ approximates a normal distribution with the following average $(E)$ and variance (Var):

$$
E(R)=\frac{N+2}{2}, \operatorname{Var}(R)=\frac{N(N-2)}{4(N-1)} .
$$

The $Z$ statistic is defined as:

$$
Z=\frac{R-E(R)}{\sqrt{\operatorname{Var}(R)}} .
$$

The T-test resulted in homogenous and statistical significance at $95 \%$ confidence limit. Thus, precipitation time series can be taken as homogeneous during the study period. Then, drought analysis was based on the annual, seasonal and monthly precipitation data.

Departure from the mean, which is called individual deviation, was calculated because it provides information about precipitation fluctuations and allows the comparison among data from different time scales (Buishand, 1982; Lazaro et al., 2001; Tošić and Ukasevic, 2005; Lui et al., 2012). Then, the completion of cumulative deviation curve, which is a statistical procedure for determination of the possible presence of fluctuations, was used to analyze precipitation trends. This method is helpful for examination of non-abrupt changes in the data series. It can also provide information about differentiation of wet and dry periods. The cumulative sums deviations were computed by using following formula and graphically depicted as a function of $k$, with $k=1,2, \ldots, n$.

$$
S_{k}=\sum_{n=1}^{k}\left(X_{i}-X_{m}\right) \text {. }
$$

Where, $\mathrm{S}_{k}$ is the sums of deviations; $\mathrm{X}_{i}$, an annual precipitation; $\mathrm{X}_{m}$, an average of long-term precipitation. A precipitation change in the series can be determined by a change in the slope of the progression of points showing $\mathrm{S}_{k}$ (Buishand, 1982; Osanaiye and Talabi, 1989; Tošić and Ukasevic, 2005).

To identify distribution of extreme precipitation events, we calculated high and low precipitation extremes using percentile for each month, season and year as threshold (Lazaro et al., 2001). The data were converted to percentile ranks from annual low extremes $(\mathrm{Q} 10)$ to the annual high extremes (Q90). The $90^{\text {th }}, 75^{\text {th }}, 50^{\text {th }}, 25^{\text {th }}$ and $10^{\text {th }}$ percentiles of monthly, seasonal annual data were computed. The Q75 was used for the upper abnormal year and Q25 for the lower abnormal year.

Standard Precipitation Index (SPI), which is used in this study, was developed by McKee et al. (1993, 1995) to examine drought conditions. SPI can be calculated by using the long-term precipitation data for the desired time scales (Khan et al., 2008).

Standardized Precipitation Index used in this study is calculated as follows:

$$
D I(S P I)=\frac{\left(X_{i}-X_{m}\right)}{S D} .
$$

Where, $D I$ is the drought index; $X_{i}$, annual, seasonal and monthly precipitation; $X_{m}$, long-term mean; $S D$, standard deviation.

SPI can identify the level of drought or wetness by examining 1-, 3-, 6-, 12- and 24-monthly precipitation totals as comparing to the historical precipitation period in the area. Interpretations of the SPI could be different according to time scales used in the study. For example, the 1-month SPI can be used to interpret short term drought conditions which can be related to soil moisture. On the other hand, the 3-month SPI can provide a seasonal estimation of precipitation, while the 6- and 9-month SPI shows meso-scale trends in precipitation conditions (Wu et al., 2001). Finally, the 12-month SPI represents the long-term precipitation 
Table 1 Standardized Precipitation Index (SPI) drought categories

\begin{tabular}{cc}
\hline SPI & SPI category \\
\hline 2.00 & Extremely wet \\
$1.50-1.99$ & Severely wet \\
$1.00-1.49$ & Moderately wet \\
$0-0.99$ & Mildly wet \\
$-0.99-0$ & Mild drought \\
$-1.49--1.00$ & Moderate drought \\
$-1.99--1.50$ & Severe drought \\
$\leq-2.00$ & Extreme drought \\
\hline
\end{tabular}

variations. Short-time scales, such as months or weeks, are important to agricultural activities while long-term occurrences such as years can be vital to water supply management systems in terms of stream flows, reservoirs and even groundwater levels.

The SPI values (and corresponding drought intensity) may be classified into several categories (Table 1; McKee et al., 1993; Giddins et al., 2005). The SPI is a dimensionless index which negative values indicate drought; positive values mean wet conditions. Monthly, seasonal and annual precipitations from all four stations were used for SPI calculation and additional cumulative deviation sums for annual precipitation were calculated as well.

\section{Results}

In this study, we examined drought conditions in Antakya-Kahramanmaraş Graben for the period of 1975-2010. The four stations are located in the Mediterranean region of Turkey (Fig. 1).

The four stations depend heavily on precipitation for their water supply. Precipitation is characterized by a typical annual pattern during summer months (on average for Kahramanmaraş $7.47 \mathrm{~mm}$, İslahiye 9.67 mm, Antakya $29.45 \mathrm{~mm}$ and Samandağ $26.42 \mathrm{~mm}$ ) and high precipitation during winter months (on average for Kahramanmaraş $366.92 \mathrm{~mm}$, İslahiye 423.52 $\mathrm{mm}$, Antakya $521.46 \mathrm{~mm}$ and Samanda $403.83 \mathrm{~mm}$ ) (Fig. 2). During the summer months, most of the water supply to the study area, which is used for irrigation, domestic and industry, comes from reservoirs and ground water.

Statistical characteristics of the annual, seasonal and monthly precipitation amounts were tested. The results represented that the data distributed in normal despite of slight positive skewness. According to the descriptive statistical results, winter months showed smaller CV (coefficient of variation), which means that December, January and February are the homogenous months in terms of precipitation variations. On the other hand, summer had the largest $\mathrm{CV}$ with all three months. Spring and autumn depicted similar precipitation patterns representing smaller variation during the study period. The September resembled to summer months in terms of precipitation variations.

The study area, which has fertile alluvial plains such as Amik and Kahramanmaraş, is experiencing increasing pressure on its water resources because of demands for growing population and industry and intensive agricultural activities. The area is prone to frequent extreme climatic phenomena such as unexpected winter drought as frequently happened in last decade and in recent years (2013-2014). These types of weather conditions represent that the study area is very sensitive to precipitation fluctuations and variability. The seasonal variability of the precipitation regime of the area also appears to be more obvious during summer months.

The monthly, seasonal and annual drought occurrences were analyzed on the Kahramanmaraş, İslahiye, Antakya and Samandağ stations. In the Tables 1 and 2, cumulative drought occurrence is expressed at multiple-time steps for varying drought categories. The numbers were obtained by accumulation probabilities of drought occurrences in each drought category. SPI values for 1 month and 12-month time scales were calculated and depicted in Table 2 for four stations. The negative values of the SPI show that recently the sites in the study are experiencing drought conditions. According to the SPI calculation of 12 months, 21 years out of 36 years represented negative precipitation anomaly for Kahramanmaraş and İslahiye, 19 years for Antakya and 17 years for Samandağ (Table 2; Fig. 3). The results showed that there was no obvious difference in the total number of drought years among four stations. A number of important drought years for the stations also do not differ significantly. The years of 3 (Kahramanmaraş), 6 (İslahiye), 4 (Antakya) and 5 (Samandağ) were moderately, severe and extremely dry years, which means that the rates of occurrence of 
the meteorological drought in the area were between $8.3 \%-16.6 \%$ (Table 2). According to annual SPI results, extreme drought occurred only in Samandağ during the study period.

For all stations, the numbers of dry years are more than wet years (Fig. 3). Monthly SPI analyses revealed that various levels of drought $(135,157,126$ and 137 months for Kahramanmaraş, İslahiye, Antakya and Samandağ, respectively) occurred during the study period (total 432 months).

In terms of analysis on annual precipitation, the worst drought years were 1999 for Kahramanmaraş (SPI $=-1.72), 1993$ for İslahiye (SPI $=-1.92), 1989$ for Antakya (SPI= -1.71) and 1993 for Samandağ (SPI= -2.16). During these years, 10 months per year showed significant amount of precipitation reduction compared with the average precipitation for all four stations. In these drought years, total precipitation was around $442.7 \mathrm{~mm}$ for Kahramanmaraş, $415.9 \mathrm{~mm}$ for İslahiye, $600 \mathrm{~mm}$ for Antakya and $466.8 \mathrm{~mm}$ for Samandağ. These values corresponded to precipitation reductions of $39.52 \%, 49.85 \%, 46.63 \%$ and $47.85 \%$, respectively.

The cumulative sums of deviations were calculated over the 36 years period for understanding on the precipitation series and differentiate wet/dry periods for annual precipitation (Somorowska, 2011; Liu et al., 2012; Chakraborty et al., 2013) and depicted in the Figs. 4-7. According to figures, apparent wet and dry periods can be distinguished. The succession of wetter years than normal years for Antakya and İslahiye started in the 1980s, on contrary, that for Kahramanmaraş and Samandağ started with negative trends. The next five years or so were characterized by consistently lower precipitation amounts than normal. During this period the annual amounts differed only slightly from the long term means for the stations of Antakya and İslahiye compared to other two sites. There was a single year with higher precipitation amounts than normal for Antakya and Samandağ. Second part of the 1980s started with positive trend and ended with downward trend. A succession of very dry years occurred in the period of 1988-1995 for most of the stations, after which precipitation in the graben returned to the long-term average. The pattern for the cumulative deviations for Kahramanmaraş is different from all other stations for the period of last ten

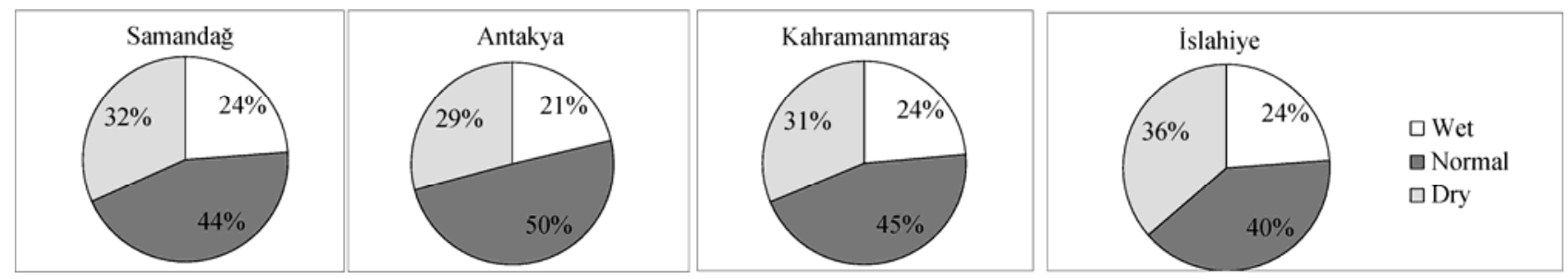

Fig. 3 Distributions of wet, normal and dry months (wet, SPI (Standardized Precipitation Index)>0.5; normal, $-0.5 \leq$ SPI $\leq 0.5$; dry, $\mathrm{SPI}<-0.5)$ in the four meteorological stations

Table 2 Standardized Precipitation Index (SPI) categories and their corresponding monthly and annual distribution (McKee et al., 1993)

\begin{tabular}{|c|c|c|c|c|c|c|c|c|c|}
\hline \multirow{2}{*}{ SPI } & \multirow{2}{*}{ SPI category } & \multicolumn{2}{|c|}{ Kahramanmaraş } & \multicolumn{2}{|c|}{ İslahiye } & \multicolumn{2}{|c|}{ Antakya } & \multicolumn{2}{|c|}{ Samandağ } \\
\hline & & Annual & Monthly & Annual & Monthly & Annual & Monthly & Annual & Monthly \\
\hline$\geq 2.00$ & Extremely wet & 2 & 26 & 0 & 22 & 1 & 22 & 1 & 21 \\
\hline $1.50-1.99$ & Severe wet & 2 & 24 & 3 & 12 & 1 & 13 & 2 & 17 \\
\hline $1.00-1.49$ & Moderately wet & 0 & 13 & 3 & 26 & 3 & 23 & 1 & 18 \\
\hline $0-0.99$ & Mildly wet & 11 & 104 & 9 & 98 & 12 & 87 & 15 & 105 \\
\hline$-0.99-0$ & Mild drought & 18 & 232 & 15 & 242 & 15 & 251 & 12 & 235 \\
\hline$-1.49--1.00$ & Moderate drought & 2 & 29 & 4 & 27 & 2 & 30 & 2 & 32 \\
\hline$-1.99--1.50$ & Severe drought & 1 & 2 & 2 & 4 & 2 & 6 & 2 & 3 \\
\hline$\leq-2.00$ & Extreme drought & 0 & 2 & 0 & 1 & 0 & 0 & 1 & 1 \\
\hline
\end{tabular}


years. During this period, the persistent and prolonged drought conditions occurred in Kahramanmaraş.

As can be seen from Figs. 4-7, the 12-month SPI analysis shows that the recent drought started in 1999 and ended in 2009 (except 2003) for Kahramanmaraş, İslahiye and Antakya. The study area experienced the same intensity drought as occurred in 1977, 1979, 1982-1985 and 1989-1995. Droughts of 1982 and 1999 are much more severe drought conditions than the other droughts for Kahramanmaraş. Worst droughts occurred in 1989-1990 and 1993 for Antakya and Samandağ, in 1993 and 1999 for İslahiye. As can be observed from the cumulative deviations in Figs. 4-7, 2 or 3 years (1981-1982 and 1995-1997) of above average precipitation in Kahramanmaraş were followed by the intensive historical droughts with very low precipitation for 3 or 4 years (1982-1985 and 1999-2002). Similar precipitation fluctuation can be observed for the other stations. For example, 2 or 3 years (1980-1981 and 1987-1988) of above average precipitation in İslahiye were followed by the a more intensive historical droughts as well with very low precipitation for 4 or 5 years
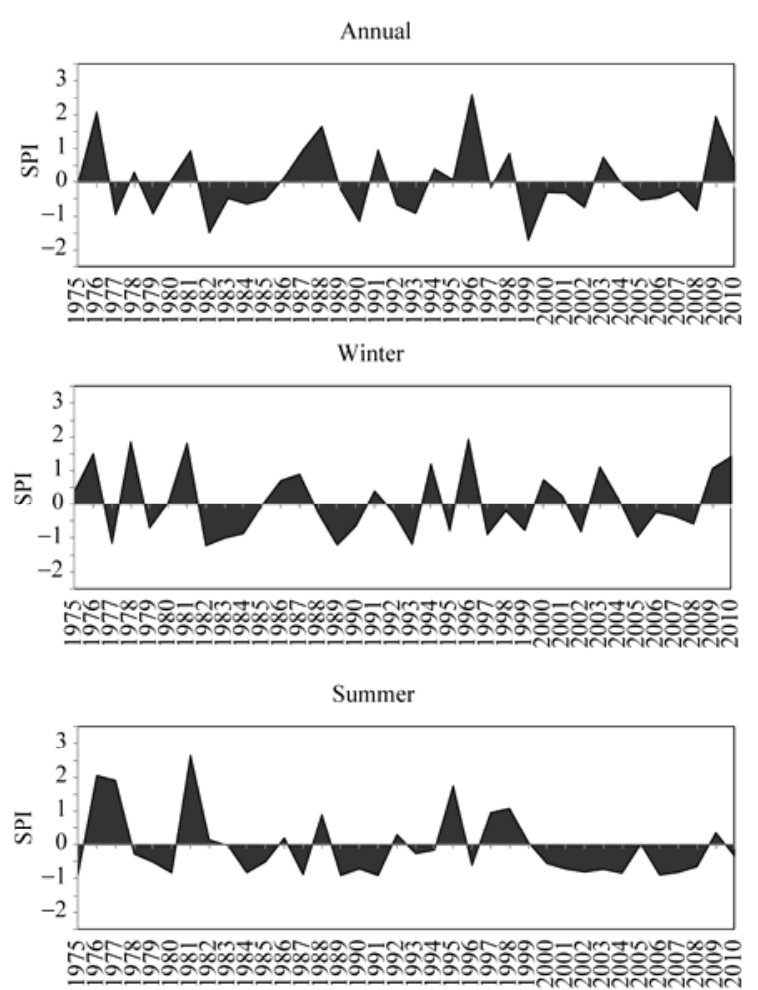

(1982-1985 and 1989-1994). Overall, the SPI demonstrated that the study area was experiencing a drought since 1998 because none of the sites have recorded real above average-level precipitation in the past 10 years with the exception of the year 2003. The latest drought was followed by above average precipitation in 2009 in Kahramanmaraş.

In general, this analysis showed that the droughts of 1989-1994 for Antakya, Samandağ and İslahiye and 1999-2002 for Kahramanmaraş are the worst drought that has occurred in recorded history for the area. However, last ten years are also one of the most prolonged droughts in the recorded history for Kahramanmaraş. Other locations showed similar trends for last ten years, which is not quite as dramatic as Kahramanmaraş. Cyclic characters of drought have pronounced clearly in all four stations. As can be seen from the cumulative deviations in Figs. 4-7 and 2-4 years of above average precipitation would have followed by the more intensive droughts with very low precipitation for 4 or more years.

For identifying normal climate events, we computed wet and dry annual, seasonal and monthly percentages.
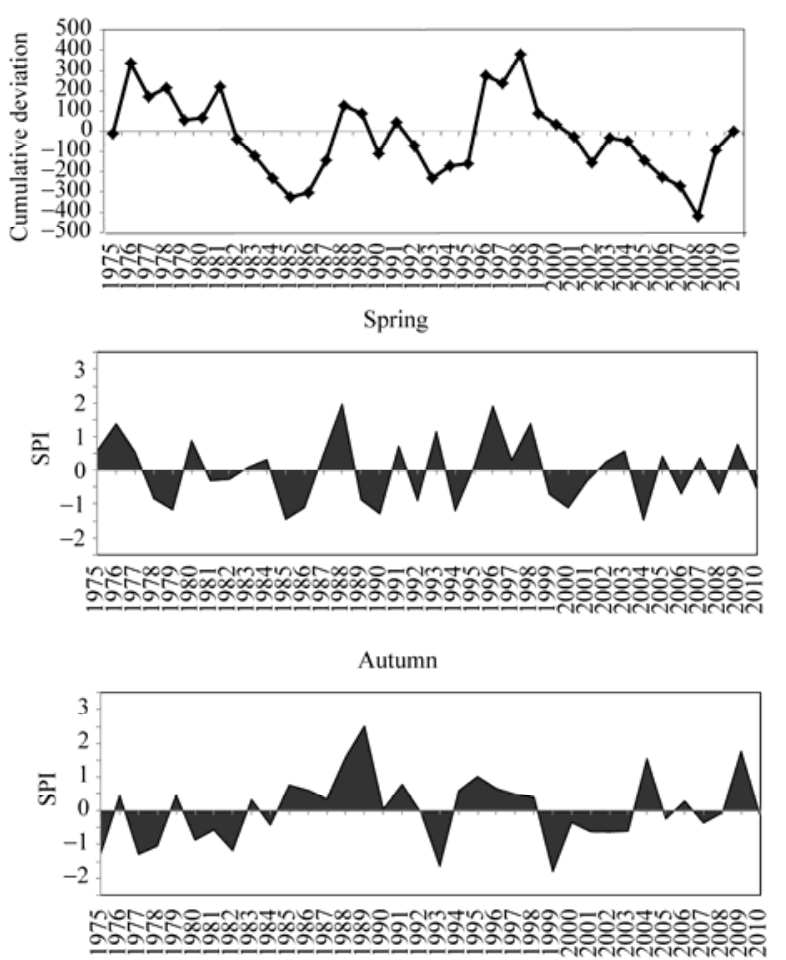

Fig. 4 Standardized Precipitation Index (SPI) distributions and cumulative precipitation deviations of annual and seasonal for Kahramanmaraş meteorological station from 1975 to 2010 


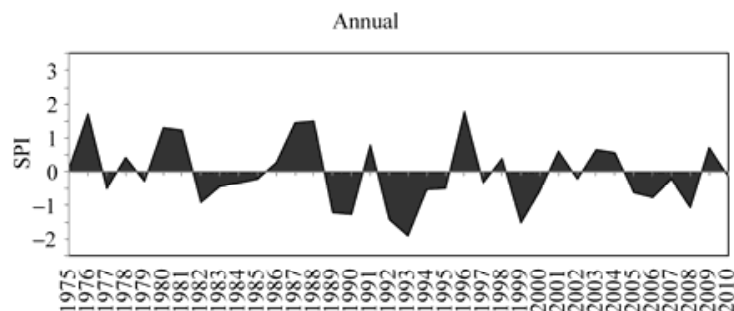

Winter

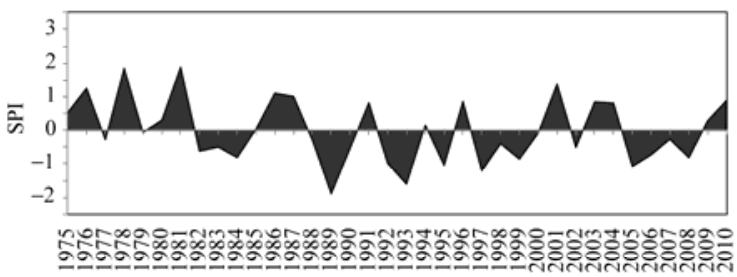

Summer

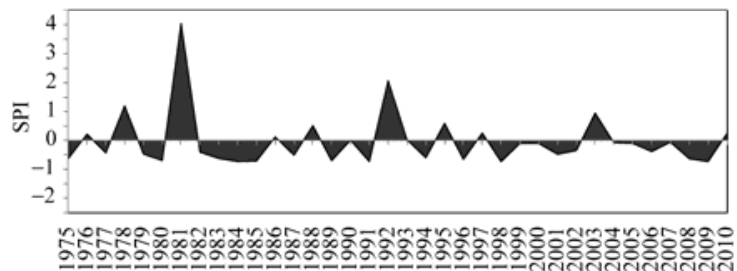

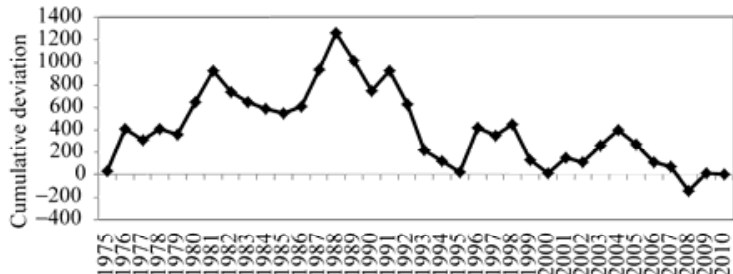

Spring

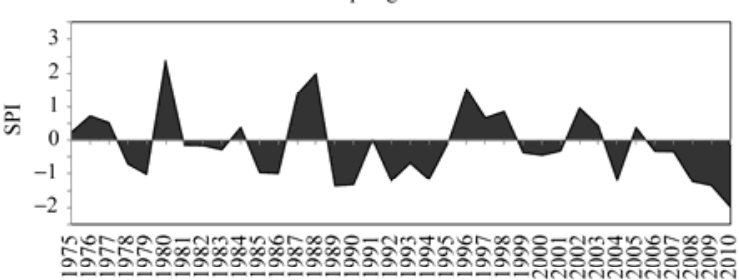

Autumn

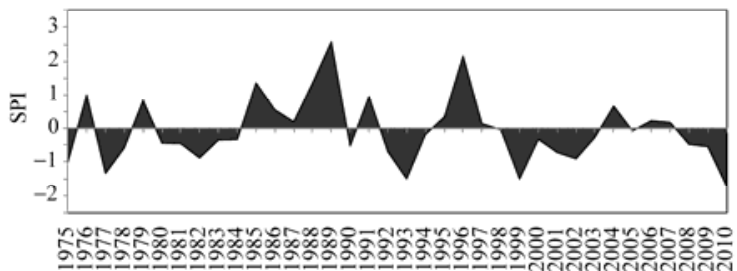

Fig. 5 Standardized Precipitation Index (SPI) distributions and cumulative precipitation deviations of annual and seasonal for İslahiye meteorological station from 1975 to 2010

Annual

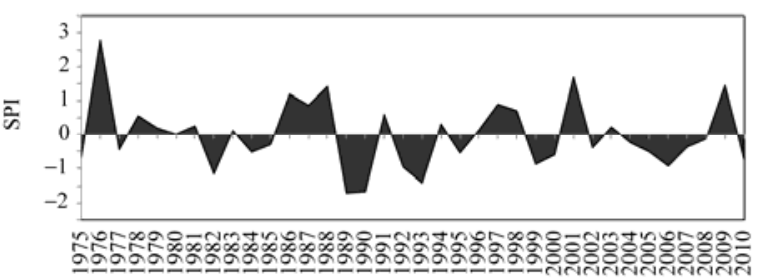

Winter

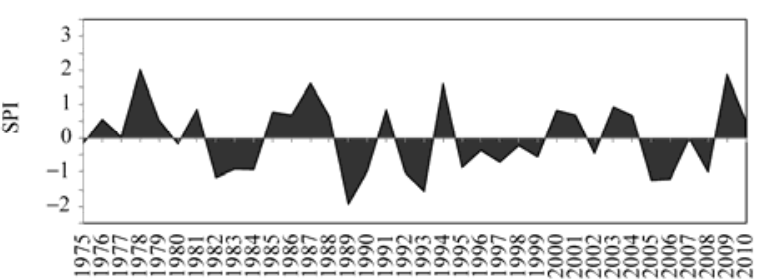

Summer

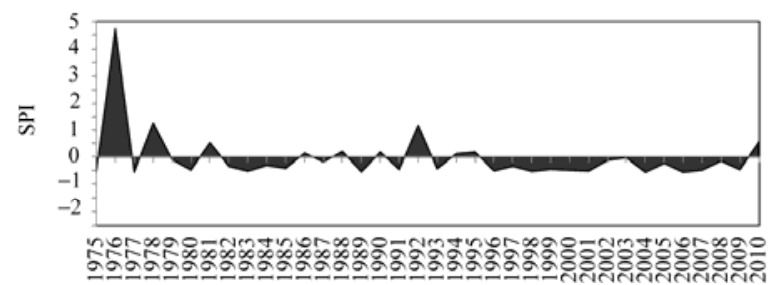

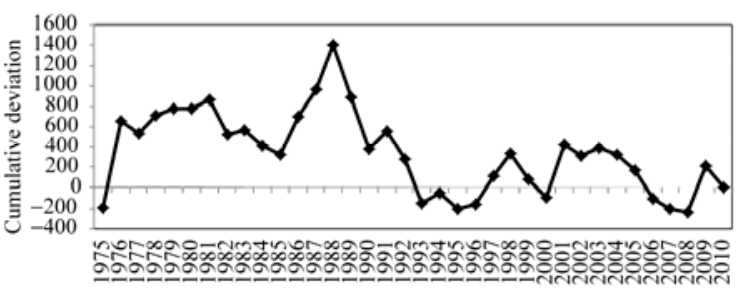

Spring

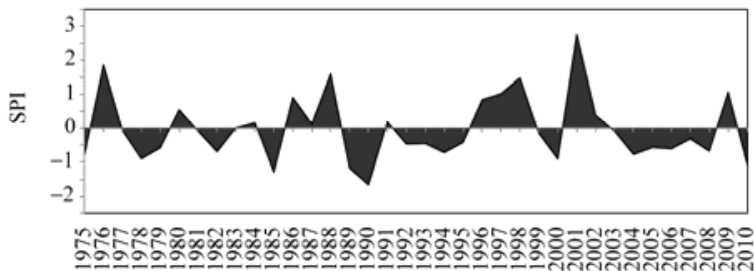

Autumn

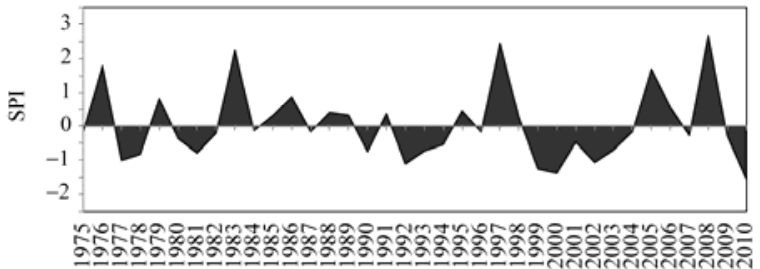

Fig. 6 Standardized Precipitation Index (SPI) distributions and cumulative precipitation deviations of annual and seasonal for Antakya meteorological station from 1975 to 2010 

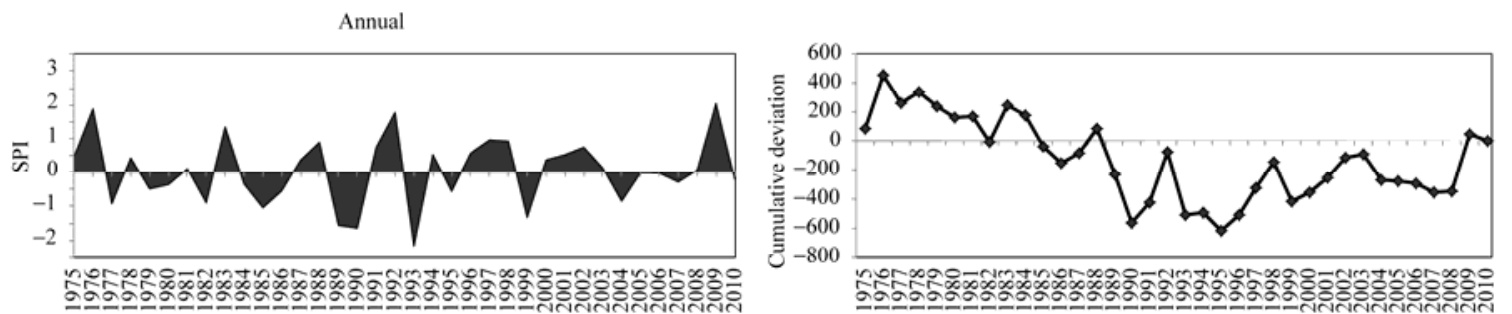

Winter
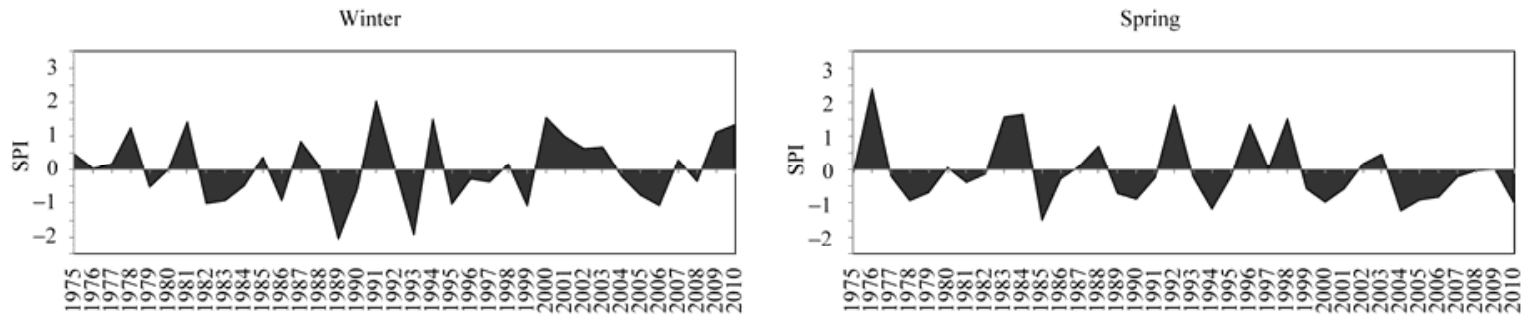

Summer
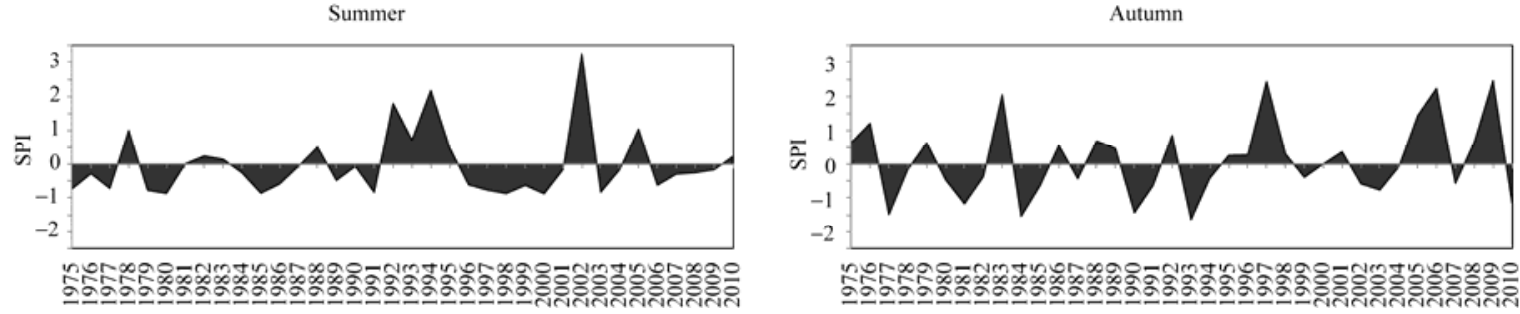

Fig. 7 Standardized Precipitation Index (SPI) distributions and cumulative precipitation deviations of annual and seasonal for Samandağ meteorological station from 1975 to 2010

Precipitation amount was considered normal between Q25 and Q75, Q25 was considered as drier than normal and called low abnormal year, season or month. Similarly, over P75 was accepted as wet year, season or month for the study area. The frequency results of dry and wet months were represented in Fig. 8. It can be seen that low number of abnormal months were distributed almost evenly throughout the study period. While for the summer season, absolute frequency of low abnormal months was the highest, and the winter showed low frequency in terms of absolute frequency of dry months. According to Fig. 8, absolute frequencies of high abnormal (wet) months were increased during the period of 1995-1998. In general, last five year showed lower frequency of wet months. Especially, autumn had high frequency of wet months during the study period.

\section{Discussion}

We have known that the current climate fluctuations and anomalies result from human activities (IPCC, 2007; Turkeş, 2011). The impacts of such anomalies vary globally, regionally and locally and led changes in the frequency of storms, and extreme weather phenomena such as flood or drought. The study area, which is located in the eastern part of the Mediterranean region in Turkey, is among those areas most likely to experience strong precipitation variations for short and long time periods. Thus, it is vital to evaluate drought conditions in the area.

From precipitation data series, it can be seen that precipitation characteristics of the area have changed with more prolonged and frequent drought events for the period of studies. This study also indicated that total precipitations of winter, spring and summer were slightly decreased. According to cumulative deviations curves (Figs. 4-7) the study area has experienced couple of dry and wet periods during the period of 1975-2010. This curve of precipitation decrease in last ten years became apparent for most of the stations. Results also revealed that despite of the slight positive trend in autumn precipitation (Huseyinova et al., 2009), drought occurred in the study area in winter and spring, and the most notable events were in the 

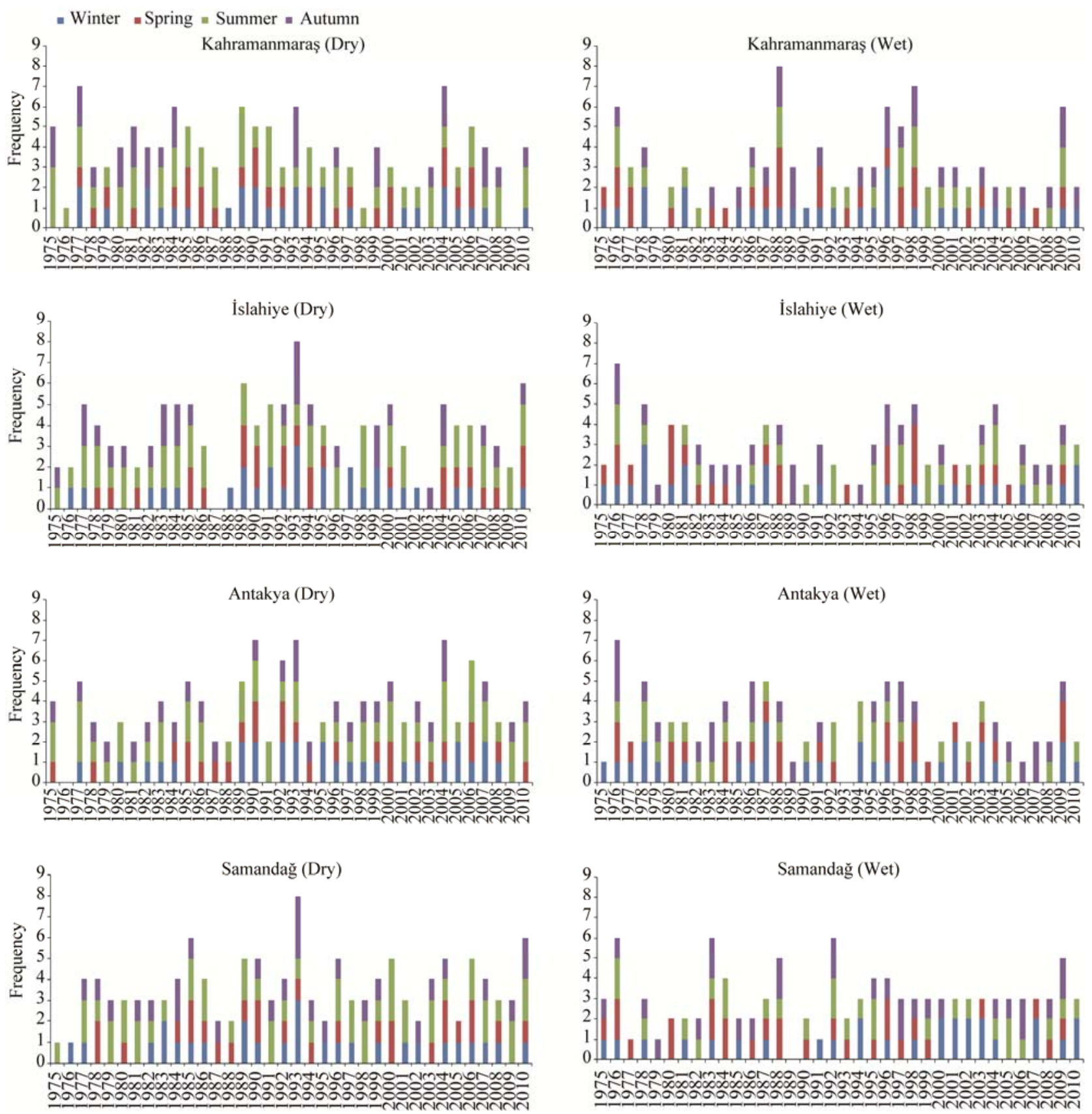

Fig. 8 Absolute frequency of dry and wet months of four meteorological stations

winter. Trends in SPI data series depicted that the proportion of the graben drought condition has significantly changed during the period under study. It is worth to be mentioned that in reality significant drought events in the last decades presented severe challenges to the water supply of the area due to the lowering water storage of reservoir systems. In particular, according to the report of State Water Agency (SWA, 2015), the persistent and prolonged drought of 2008 seriously affected dams and reservoirs by low- ering water level almost $75 \%$ in Kahramanmaraş.

According to literature (Türkeş, 1998; Türkeş and Erlat, 2005), large-scale atmospheric circulation patterns had a significant effect on Turkey's total precipitation. For example, during the rainy season, the air masses which produce precipitation in Turkey are controlled by the large-scale Siberia anticyclone, polar front cyclones and Mediterranean depressions. In particular, air masses originate from North Atlantic Ocean cause precipitation in the study area by passing 
over Mediterranean and becoming instable with subsequent warming (Tatli et al., 2004; Şariş et al., 2010). In addition, several recent studies have also described the other factors that have a direct controlling effect on the amount and distribution of precipitation in Turkey and Mediterranean region. These factors consists of strength of anticyclonic flow, mid-latitude cyclone track and frequency, extension and strength of polar fronts, proximity to the oceanic, local and regional topographic conditions, stages of the North Atlantic Oscillation, location and strength of 700 and $500 \mathrm{hPa}$ height anomalies (Deniz and Karaca, 1995; Karaca et al., 2000; Türkeş et al., 2002; Türkeş and Erlat, 2005). Between October and June, which can be considered as rainy season, mid-latitude cyclone track and frequency have significant impact on regional distribution of precipitation. In the study area, drought events can be associated with shifts in general atmospheric circulation patterns such as location of jet streams, storm tracks, and changes of the 700 and 500 $\mathrm{hPa}$ height series and monsoon circulations or with variations in the thermodynamic conditions of the atmosphere (Deniz and Karaca, 1995; Türkeş, 1998; Xoplaki et al., 2004). Therefore, negative SPI values of winter and spring may have been associated with the dominance of the anticyclonic circulation during the study period, due to increased atmospheric geopotential heights and decreased cyclone activity over Turkey (Türkeş, 1998; Türkeş et al., 2007). Türkeş and Erlat (2005) have also pointed out that winter time precipitation variability of Mediterranean region is clearly associated with large scale North Atlantic Oscillations. Drought conditions detected was therefore related to the intensification of the Azores high pressure, which causes northward shifts of storm tracks from the Mediterranean towards western and northern Europe that produce the dry conditions over the Mediterranean region (Xoplaki et al., 2006; Türkeş et al., 2007).

\section{Conclusion}

Drought is one of the most damaging and complex natural disasters that impact society and living organisms throughout the world and Turkey. The impacts of drought can be extensive both spatially and timely with severe economic, environmental and social con- sequences. Therefore, every nation must have drought mitigation plan in order to reduce impacts associated with drought.

From the analyses of SPI and cumulative deviations for annual (12 months), seasonal (3 months) and monthly precipitation data series it can be concluded that precipitation characteristics of the area is changing and drought events becoming more frequent for the period of study area. The patterns of different year types, including those with dry winters or dry springs and wet autumns, seemed to increase during the most recent decade, affecting water availability when it is most critical for the agriculture. This result is consistent with the analysis of precipitation trends of Turkey (Türkeş, 1996; Türkeş et al., 2007; Huseyinova et al., 2009). Trends in SPI values also indicated that the study area experiencing extreme and/or moderate drought conditions has changed significantly during the last 30 years. Spatially, changes in the precipitation amounts are found to be variable, with a significant shift towards drier conditions observed over northern part of the study area starting by late 1980s. Trends are the strongest in winter and the weakest in the autumn. Analysis of meteorological drought represents that the area is exposed to drought events rather frequently. Historical records of meteorological drought in the region show that several drought events occurred in the periods of 1977-1980, 1981-1985 and 1989-1995. As a result, these meteorological drought periods were associated with hydrological and water resources drought resulted in significant decrease in the water levels in dams and reservoirs.

According to literature (Türkeş, 1998), frequent drought events may have been associated with the dominance of the anticyclonic circulation due to mainly increased atmospheric geopotential heights and decreased cyclone activity in Eastern Mediterranean. The droughts in the area over the study period vary from dry through moderately dry to very dry according to the calculated SPI values. We found that drought magnitudes vary over the study period with crests and troughs. Drought magnitudes for the area spread from one month (with magnitude 1) to several months. This can cause severe effects on agriculture and water supply systems if it occurred. For mitigating 
effects of prolonged drought events, local government should prepare proper drought management plans. Considering the longest dry periods ever recorded Water resource planners or related professionals should come up with drought planning and mitigation programs. The findings in this study may contribute to improve drought preparedness by highlighting the risks of droughts in agriculturally important areas in Turkey. Finally, this paper has also proved that the SPI method is a simple and effective tool for the study of drought.

\section{References}

Beniston M. 2007. Current and future trends of climatic extremes in Switzerland. Geography Compass, 1(4): 739-751.

Bonaccorso B, Bordi I, Cancelliere A, et al. 2003. Spatial variability of drought: an analysis of the SPI in Sicily. Water Resources Management, 17: 273-296.

Bordi I, Frigio S, Parenti P, et al. 2001. The analysis of the standardized precipitation index in the Medditerranean area: large-scale patterns. Annals of Geophysics, 44: 965-978.

Bordi I, Fraedrich K, Petitta M, et al. 2005. Large-scale analysis of drought in Europe using Ncep/Ncar and Era-40 re-analaysis data sets. European Water, 9(10): 35-42.

Buishand T A. 1982. Some methods for testing the homogeneity of rainfall records. Journal of Hydrology, 58: 11-27.

Burn D H, Elnur M A H. 2002. Detection of hydrologic trends and variability. Journal of Hydrology, 225: 107-122.

Chakraborty S, Chaube U C, Mishra S K, et al. 2013. Trend and variability analysis of rainfall series at Seonath River Basin. Chhattisgarh (India). Journal of Applied Sciences and Engineering Research, 2 (4): 425-434.

Deniz A, Karaca M. 1995. Analysis of cyclone tracks over Turkey. Journal of ITU, 53: 59-66. (in Turkish)

Dracup J A, Lee K S, Paulson E G. 1980. On the definition of droughts. Water Resources Research, 16(2): 297-302.

Eshel G, Farrell B F. 2000. Mechanisms of Eastern Mediterranean rainfall variability. Journal of Atmospheric Sciences, 57: 3219-3232.

Giddins L, Soto M, Rutherford B M, et al. 2005. Standardized precipitation index zones for Mexico. Atmósfera, 18(1): 33-56.

Huseyinova R, Kulbay H G, Bilgin A, et al. 2009. Precipitation trends in Kahramanmaraş along with Gaziantep and Adıyaman during the period of 1963-2005. Ekoloji, 18(71): 15-27.

IPCC. 2007. Climate Change 2007: The Physical Science Basis. Cambridge: Cambridge University Press.

Kadioğlu M. 2000. Regional variability of seasonal precipitation over Turkey. International Journal of Climate, 20: 1743-1760.

Khalil A, El-Kadi A. 2001. Variation of rainfall and drought conditions in Gaza-Palestine: on a regional and global context. Journal of the Islamic University of Gaza, 2: 41-66.
Khan S, Gabriel H F, Rana T. 2008. Standard precipitation index to track drought and assess impact of rainfall on water tables in irrigation areas. Irrigation and Drainage Systems, 22: 159-177.

Koçman A, Işık Ş, Mutluer M. 1995. Rainfall variability and drought problems in the Aegean plains. Aegean Geographical Journal, 8: 25-36.

Kömüşçü A Ü, Erkan A. 2011. Drought and an overall assessment for Turkey. State Meteorology Works. [2014-05-20]. http//:www.mgm.gov.tr.

Lazaro R, Rodrigo F S, Gutierrez L, et al. 2001. Analysis of a 30-year rainfall record (1967-1997) in semi-arid SE Spain for implications on vegetation. Journal of Arid Environments, 48: 373-395.

Liu D, Guo S, Chen X, et al. 2012. Analysis of trends of annual and seasonal precipitation from 1956 to 2000 in Guangdong Province, China. Hydrological Sciences Journal, 57(2): 358-369.

McKee T B, Doesken N J, Kleist J. 1993. The relationship of drought frequency and duration to time scales. Eighth Conference on Applied Climatology, 17-22 January, Anaheim, California: American Meteorological Society, 179-184.

Moreira E E, Paulo A A. Pereira L S, et al. 2006. Analysis of SPI drought class transitions using loglinear models. Journal of Hydrology, 331: 349-359.

Nalbantis I, Tsakiris G. 2009. Assessment of hydrological drought revisited. Water Resources Management, 23: 881-897.

Osanaiye P A, Talabi C O. 1989. On some non-manufacturing applications of counted data cumulative sum control chart schemes. The Statistician, 38: 251-257.

Pamuk G, Özgürel M, Topçuoğlu K. 2004. Drought analysis in the Aegean region with standardized precipitation index (SPI). Journal of Agriculture, 41(1): 99-106.

Panu U, Sharma T. 2002. Challenges in drought research: some perspectives and future directions. Hydrological Sciences Journal, 47: 19-29.

Ramos M C. 2001. Rainfall distribution patterns and their change over time in a Mediterranean Area. Theoretical and Applied Climatology, 69: $163-170$.

Sariş F, Hannah D M, Eastwood W J. 2010. Spatial variability of precipitation regimes over Turkey. Hydrological Sciences Journal, 55(2): 234-249.

Shahabfar A, Eitzinger J. 2013. Spatio-temporal analysis of droughts in semi-arid regions by using meteorological drought indices. Atmosphere, 4(2): 94-112.

Sirdaş S, Şen Z. 2003. Meteorological drought modelling and application to Turkey. Istanbul University Engineering Journal, 2(2): 95-103. (in Turkish)

Smakhtin V U, Hughes D A. 2004. Review, automated estimation and analyses of drought indices in South Asia Working Paper 83. Colombo, Srilanka: International Water Institute.

Somorowska U. 2011. Temporal changes in precipitation impacting groundwater and stream flow. Die Bodenkultur, 62: 115-121.

Sönmez K, Kömüşçü A Ü, Erkan A, et al. 2005. An analysis of spatial and temporal dimension of drought vulnerability in turkey using the standardized precipitation index. Natural Hazards, 35: 243-264.

SWA. 2015. Climate change and adaptation. [2015-03-08]. 
http//:www.dsi.gov.tr.

Tabari H, Abghari H. Talaee P H. 2012. Temporal trends and spatial characteristics of drought and rainfall in arid and semiarid regions of Iran. Hydrological Processes, 26: 3351-3361.

Tatli H, Dalfes N, Menteş S. 2004. A statıstıcal downscalıng method for monthly total precipitation over Turkey. International Journal of Climatology, 24: 161-180.

Thornthwaite C W. 1948. An approach toward a rational classification of climate. Geographical Review, 38: 55-94.

Tošić I, Ukašević M. 2005. Analysis of precipitation series for Belgrade. Theoretical and Applied Climatology, 80: 67-77.

Türkeş M. 1996a. Meteorological drought in Turkey: a historical perspective, 1930-1993. Lincoln: University of Nebraska, 17-21.

Türkeş M. 1996b. Spatial and temporal analysis of annual rainfall variations in Turkey. International Journal of Climatology, 16: 1057-1076.

Türkeş M. 1998. Influence of geopotential heights, cyclone frequency and southern oscillation on rainfall variations in Turkey. International Journal of Climatology, 18: 649-680.

Türkeş M. 2001. Weather, climate and severe weather events and global warming. Turkish Prime Ministry General Directorate of State Meteorological 2000 Seminars. Ankara: Technical Presentations, Seminar Series, 1: 187-205.

Türkeş M, Sümer U M, Kiliç G. 2002. Persistence and periodicity in the precipitation series of Turkey and associations with $500 \mathrm{hPa}$ geopotantial heights. Climate Research, 21: 59-81.

Türkeş M. 2003. Spatial and temporal variations in precipitation andaridity index series of Turkey. In: Bolle H J. Mediterranean Climate.Berlin: Springer Verlag, 181-213.

Türkeş M, Erlat E. 2005. Climatological responses of winter precipitation in Turkey to variability of the North Atlantic Oscillation during the period 1930-2001. Theoretical and Applied Climatology, 81: 45-69.

Türkeş M, Koç T, Sariş F. 2007. Spatial and temporal analysis of the changes and trends in precipitation total and intensity series of Turkey. Turkish Journal of Geographical Sciences, 5: 57-73. (in Turkish)

Türkeş M, Akgündüz A S, Demirörs Z. 2009a. Drought periods and severity over the Konya Sub-region of the Central Anatolia Region according to the Palmer Drought Index. Journal of Geographical Sciences, 7(2): 129-144. (in Turkish)

Türkeş M, Koç T, Sariş F. 2009b. Spatiotemporal variability of precipitation total series over Turkey. International Journal of Climatology, 29: $1056-1074$.

Türkeş M, Tatli H. 2009. Use of the standardized precipitation index (SPI) and a modified SPI for shaping the drought probabilities over Turkey. International Journal of Climatology, 29: 2270-2282.

Türkeş M. 2011. Hydroclimatological and time-series analysis of variations in precipitation and aridity index series of the Akhisar and Manisa districts and geographical synthesis of their consequences with respect to desertification. Journal of Geographical Sciences, 9(1): 79-99. (in Turkish)

Xoplaki E, González-Rouco J F, Luterbacher J, et al. 2004. Wet season Mediterranean precipitation variability: influence of large-scale dynamics and trends. Climate Dynamics, 23: 63-78.

Xoplaki E, Luterbacher J, González-Rouco J F. 2006. Mediterranean summer temperature and winter precipitation, large-scale dynamics, trends. IL Nuovo Cimento, 29: 45-54.

Wilhite D A, Glantz H M. 1995. Understanding the drought phenomenon: the role of definitions. Water International, 10(33): 110-120.

Wu H, Hayes M J, Weiss A, et al. 2001. An evaluation of the Standardized Precipitation Index, the China- $Z$ Index and the statistical Z-Score. International Journal of Climatology, 21: 745-758. 